\title{
Consequential Effects of Defence Expenditure on Economic Growth of Saudi Arabia: 1970-2012
}

\author{
Mohammed Moosa Ageli ${ }^{1} \&$ Shatha M Zaidan ${ }^{2}$ \\ ${ }^{1}$ Assistant Professor of Economics, King Saud University, Kingdom of Saudi Arabia \\ ${ }^{2}$ Lecturer, Princess Nora University, Kingdom of Saudi Arabia \\ Correspondence: Mohammed M Ageli, Assistant Professor of Economics, King Saud University, Kingdom of \\ Saudi Arabia. E-mail: m.m.ageli@gmail.com
}

Received: October 15, 2012

Accepted: December 17, 2012

Online Published: January 10, 2013

doi:10.5539/ijef.v5n2p155

URL: http://dx.doi.org/10.5539/ijef.v5n2p155

\begin{abstract}
This study investigates the causality relationship between defence expenditures and Non Oil economic growth in Saudi Arabia over the period 1970-2012. Using Unit root tests, Johansen's co-integration test and Granger Causality test. In this paper we found the existence of bi-directional causality relationship running from Non Oil-GDP to defence expenditure. The results show that, in Saudi Arabia, the model of defence expenditure is found to hold for Non Oil-GDP.
\end{abstract}

Keywords: defence expenditure, economic growth, unit root test, co-integration test, Granger causality and Error Correction Models (ECM)

\section{Introduction}

Defence expenditure is the large and significant sectors of government expenditure in all countries. It is used as a measure of the burden imposed on the people and the national economy by defence policy. The causality relationship between defence expenditure and economic growth shows a clearly causality in all countries. According to, Al-Jarrah (2005), defence expenditure diverts resources away from productive activities and leave adverse impact on economic growth. Devoting a large proportion of government expenditure to the military would leave other important sectors like education and health with less financial resources. Moreover, defence expenditure has not only economic implications, but also, and more importantly, defence as well as political aspects.

The ultimate Goal of the paper is to examine the causality relationship between defence expenditure and Non Oil-GDP in Saudi Arabia. The objectives are:

1) To determine whether a stationary long-run relationship exists between defence spending and Non Oil economic growth in Saudi Arabia.

2) To examine the causality between these two variables.

3) To determine how defence expenditures affected Non Oil economic growth in Saudi Arabia.

Therefore, the following hypotheses are:

H0: defence expenditure has no significant impact on Non Oil-GDP in Saudi Arabia.

H1: defence expenditure has significant impact on Non Oil-GDP in Saudi Arabia.

In addition, as part of the time-series analysis, the stationary properties of the data using the ADF test real Non Oil GDP and other variables were conducted. Followed by an analysis to test whether the variables are co-integrated. Finally, we have used the Error Correction Model (ECM) to discuss the short run adjustment to equilibrium.

The paper is organised as follows: section two, presents some empirical results of relevant theoretical and empirical literature on the relationship between government expenditure and economic growth. In section three of this paper, the defence expenditure model presented. Section three, investigates the data and empirical results and analysis by using identified methods. In addition, section four, presents results of the analysis by using time series techniques, while section five, concludes the paper and presents the finding. 


\section{Defence Expenditures in Saudi Arabia}

Defence affairs are expenses related to the administration and operation of defence. Considering the geopolitical importance of the Middle East and the Gulf region and the instability associated with these regions, Saud Arabia has been investing in a great amount for the development of its defence and security forces. As mentioned previously, Gulf Wars had a huge impact and resulted in large burdens on Saudi Arabia's budget.

The ratio of defence expenditures in GDP has not shown secular trends, but rather followed ups-and-downs. As can be seen, in 1970 the ratio was about $6 \%$, which increased to $8 \%$ in 1973 . However, with the enormous increases in oil revenues in 1974 after the first oil shock and increased GDP, encouraged government to develop infrastructure projects in line with the increased GDP and therefore immediate adjustment witnessed in defence expenditure with the share of defence expenditure increasing to $9.5 \%$ in 1975 , which reached a pick at about $10 \%$ in 1978. However, in 1980 it declined to $7 \%$ since 1975 due to the global recession as a result of oil prices. Immediately, in 1981 the increasing trend in the share of defence expenditures to GDP set in and reached to $9.5 \%$ in 1983. The declining trends in the ratio were observed from 1984 to 1989 , falling to $7 \%$ in 1989 only with a pick in 1987 with 9\%. The impact of defence expenditures can immediately see in 1990 and 1991 with the share of defence expenditures in GDP increasing to $12 \%$ and $13 \%$ respectively. Since then, a decreasing trend observed in the ratio of defence expenditures to GDP, until the present times. The share of defence expenditure in real GDP in Saudi Arabia was 13\%, since 1991. The ratio of defence spending on defence fluctuated during 1990s. As we know the Gulf has witnessed three wars, which was a reason to increase the expenditures of defence in the Gulf.

Immediately after the war, the ratio fell down to about $10 \%$ and then followed a decreasing trend to $6 \%$ in 2009 . In such a declining trend, rather than defence expenditures, growth in absolute level declining, high increases in GDP as the denominator due to the oil price plays an important role.

\section{Literature Review}

According to the previous empirical studies we have the different results namely, positive, negative and neutral. Regarding to that we had divided their findings into three groups:

The First group of empirical studies found positive effects of defence expenditure on economic growth. Atesoglu (2002) examined the relationship between the defence expenditure and aggregate output in the United State economy, by implementing a quarterly data for the period 1970 to 2000 . He found a positive relationship between the variables. Most recently, in Turkey, Halicioglu (2004) also found a high correlation relationship between the level of economic growth and defence expenditure, by using data from 1950 to 2002. Benoit (1973, 1978) analysed the nexus between defence expenditure and GDP in 44 less developing countries. He found that defence military was positive correlated with economic growth. Aizenman and Glick (2003) examine the non-linear interactions between defence expenditure and growth, for 99 countries. They found that the effect of defence expenditure on growth is positive. Moreover, Brumm (1997) analysed the casualty relationship between defence expenditure and economic growth in 88 countries for the period 1974 to 1989 . He used cross-section Barro regressions. His results indicated that there is a positive correlation between the growth nexus defence expenditure. Hassan et al. (2003) investigated the relationship between defence expenditure and economic growth and FDI in some countries in South Asian Regional Cooperation Council nations (SARCC) for the period 1980 to 1999. His results present a strong support for a positive relationship between defence expenditure and economic growth. Finally, Frederiksen and Mcnab (2001) studied the causality relationship between military expenditure and economic growth in Malaysia. They proofed that there is a clear positive relationship between military and growth.

The Second group found negative effects of defence expenditure on economic growth. Yildirim and Selami (2005) investigated the relationship between the defence expenditure and the degree of democracy for the period 1987-1997, on data for up to 92 countries. They found that there is a negative implication between the variables. Deger (1986) found a negative correlation between defence expenditure and economic growth in some developed countries. Lim (1983), Degree and Sen (1983), Faini et al. (1984) and others have found a negative relation between defence and growth. Moreover, Moon and Hyun (1992) in the context of Asia found negative implications between defence and growth. Klein (2004) found a negative effect of military expenditure on economic growth in Peru, indicating the existence of crowding-out effect. Also, Lipow and Antinori (1995) argue that defence expenditure has a negative causality on economic growth. Finally, most recently, Kentor, Kick (2008) explored a relationship between military expenditure and economic growth, by using cross-national panel data regression for developed and less developed countries from 1990 to 2003. The results show the negative relationship between military expenditure and GDP. 
The Third group found mixed effects of defence expenditure on economic growth, which reached inconclusive results on the direction of causality relationship between economic growth and military expenditure, concluding. Selami and Yildirim (2002) examined the demand for Turkish defence expenditure for the period 1949-1998. They found that there is a mixed result. Their results suggested that the Turkish defence expenditure determined NATO's defence expenditure, and the short-run estimates have a significant relationship. Abu Bader and Abu Qarn (2003) examine the causality between defence expenditure and economic growth in Egypt, Syria and Israel. They found a negative impact between the military expenditure and economic growth in Egypt and positive caused in Syria and Israel. Also, Kollias et al. (2004a) found mixed results in the term of causal relationship between defence expenditure and economic growth on 15 EU countries. As well as, Study for Chowdhury (1991) who examined data for 55 developing countries and could not find any case supporting the relationship between defence expenditure and economic growth. Finally, Kim (1996) analysed "the relationship between military expenditure, the quality of life, and economic growth for 101 countries." He also found that military expenditure have no significant on economic growth.

\section{Methodology and Data}

The study will cover Saudi Arabia for the period from 1970 to 2012. The data sources are the Saudi Arabia Monetary Agency (SAMA), SIPRI defence expenditure database and International Monetary Fund Yearbook (IMF). (DEX) is measured by the Defence Expenditure as a percentage of GDP, for economic growth, it is measured by real Non Oil GDP (RNGDP). All the data used in the study were transformed into logarithm. The data used in this study consist of the following variables (table 1).

Table 1. Variables Definitions

\begin{tabular}{ll}
\hline Variable & Definition \\
\hline RNGDP & Real Non Oil Economic Growth \\
DEX & Defence Expenditure as \% of GDP \\
\hline
\end{tabular}

In this study we have to use the model (equation 1):

$$
L D E X=a+b \text { LRNGDP }
$$

\subsection{Stationarity and Unit Root Tests}

The most widely used Unit Root analysis test is Augmented Dickey-Fuller (ADF) (1981) tests. ADF test is performed by estimating the following equation (2):

$$
\Delta Y_{t}=a_{0}+a_{1} t+a_{2} Y_{t-1}+\sum_{i=1}^{k} a_{i} Y_{t-1}+e_{t}
$$

where $\Delta \mathrm{Y}=$ the first difference of the series; $Y_{t}=$ is the series under consideration (GDP, government expenditures, or government revenues); $t$ is the time trend, $k$ is the number of lag and $e_{t}$ is a stationary random error (white noise residual).

According to Charemza and Deadman (1992: 135) "the practical rule for establishing the value of $[\varphi] \ldots$ is that it should be relatively small in order to save degrees of freedom, but large enough not to allow for the existence of autocorrelation ine $e_{t}$. For example, if for $[\varphi]=2$ the Durbin-Watson autocorrelation statistic is low, indicating first order autocorrelation, it would be sensible to increase $m$ with the hope that such autocorrelation will disappear". The simple formula in Dickey-Fuller tests establish whether $\beta=1$ in the model (3):

$$
Y_{t}=\beta Y_{t-1}+e_{t}
$$

By deducting $\mathrm{Y}_{\mathrm{t}-1}$ from each side of the equation in re-writing (4), the following form is established:

$$
\Delta Y_{t}=\Omega Y_{t-1}+e_{t}
$$

where $\Omega=\beta-1$

Testing the hypothesis with $\beta=1$ is equivalent to testing the hypothesis $\Omega=0$ (Enders, 1995:221). The hypothesis are:

$$
\begin{aligned}
& H_{0:} \Omega=0 \\
& H_{1:} \Omega \neq 0
\end{aligned}
$$

These procedures are applied to each data time series in order to examine their stationary properties by conducting the tests in levels and first difference. It should be noted that failing to reject the null (H0) hypothesis 
implies unit root process. However, if the outcome indicates that the series is stationary after the first difference; the series integrated of order one I(1), then the process is continued with the co-integration test.

In testing defence expenditure, the non-stationary property of the series must be considered first. There are many alternative tests available to examine whether the series are stationary or non-stationary. If the variables under investigation are stationary, this means that the variables do not have unit roots, then the series said to be $1(0)$. If the variables under investigation are non-stationary in its level form, but stationary in its first-difference form, which means that the variables do have unit roots, then they are said to be 1(1). In recent years, the many macroeconomic time series are non-stationary which means that they contain unit roots that cause many econometric problems. To test the relationship between defence expenditures and Non Oil economic growth in the case of Saudi Arabia; we used Augmented Dickey Fuller (ADF) (1979) method to test the unit root (equation $5)$.

$$
\Delta y_{t}=\alpha+\beta y_{t-1}+\sum_{t-i}^{k} \Delta y_{t-i}+\varepsilon_{t}
$$

\subsection{Co-integration Test}

In the time-series modelling, the co-integration test is carried out if there exists a stationary linear combination of non-stationary random variables. The aim of this test is to examine whether the data demonstrate a long-run relationship.

In brief, this test refers to the situation where multiple series integrate of order (d), or in other words, I(d) where (d) represent the number of unit roots contained in the series. These can combine to produce series integrated of order $(\mathrm{k})$, where $\mathrm{k}$ can range from zero to $\mathrm{d}-1$.

According to Engle and Granger (1987), the two series are said to be co-integrated of order (d, b) if $Y_{t}$ is integrated of order $(d)$ and there exists a vector, $\beta$, such that $\beta^{\prime} Y_{t}$ is integrated of order (d-b).

An example of two co-integrated series behaves as in equation (6).

$$
Y_{t}=\alpha+\beta X_{t}+e_{t}
$$

If the residuals (et) from the regression are $\mathrm{I}(0)$, then $\mathrm{Xt}$ and $\mathrm{Yt}$ are said to be co-integrated and non-stationary. However, the linear combination is stationary. Thus, the series need to be in integration of the same order for co-integrated to be possible. In this research, the co-integration test is used to substantiate the econometric process in relation to each of the model tested.

Co-integration tests used to test the relationship between economic growth and defence expenditure. Granger (1980) was the first to propose a connection between non-stationary series and long-run equilibrium. The purpose of conducting co-integration is to explore whether the data exhibit a long-run relationship. Engle and Granger (1987) developed and introduced the theory of co-integration.

Johansen (1988), and Johansen and Juselius (1990) presented that the variables under investigate are performed for each version of Wagner's Law to search for the existence of a long-run equilibrium relationship between the two variables GE and Non Oil GDP.

\subsection{Granger Causality Test}

Granger Causality test is used for testing the long-run relationship between defence expenditure (DEX) and Non Oil GDP (NGDP) will be tested using time series data of Saudi Arabia data for the period 1970-2012. The Granger procedure is selected because it consists the more powerful and simpler way of testing causal relationship assuming that the two series contain all the information necessary for prediction X Granger-causes $\mathrm{Y}$ if lagged X's helps predict Y (Granger, 1980) equations (7), (8).

$$
\begin{aligned}
& x_{t}=\alpha_{0}+\sum_{i=1}^{r} \beta_{x t-i} x_{t-i}+\sum_{i=1}^{s} \beta_{y t-i} y_{t-i}+\varepsilon_{t} \\
& y_{t}=\alpha_{0}+\sum_{i=1}^{r} \beta_{y t-i} y_{t-i}+\sum_{i=1}^{s} \beta_{x t-i} x_{t-i}+\varepsilon_{t}
\end{aligned}
$$

For equation 7, the following hypotheses are constructed:

$\mathrm{H}_{0:} \beta_{\mathrm{xt}-\mathrm{i}}=0$, for $\mathrm{i}=1,2, \ldots \ldots \ldots \ldots, \mathrm{k}$ 
$\mathrm{H}_{1:} \beta_{\mathrm{xt}-\mathrm{i}} \neq 0$, for at least one $\mathrm{i}$

Thus, equation 7 is used to test whether $\left(\mathrm{Y}_{\mathrm{t}}\right)$ Granger causes $\left(\mathrm{X}_{\mathrm{t}}\right)$. For equation 8 , on the other hand, the hypotheses to be tested are:

$\mathrm{H}_{0:}$ Byt $-\mathrm{i}=0$, for $\mathrm{i}=1,2, \ldots \ldots \ldots \ldots . ., \mathrm{k}$

$\mathrm{H}_{1:}$ ßyt $-\mathrm{i} \neq 0$, for at least one $\mathrm{i}$

Consequently, equation 8 is used to test whether $\left(\mathrm{X}_{\mathrm{t}}\right)$ Granger causes $\left(\mathrm{Y}_{\mathrm{t}}\right)$. For variables under investigate in our study, we tested individually for the causality between the dependent variables defence expenditure DEX and Non Oil GDP (equation 9 and 10). But before doing that we have to check for the time series properties and especially co-integrating properties of the time series involved. As Oskooee and Alse (1993: 536) pointed out, "Standard Granger or Sims tests are only valid if the original time series from which growth rates are generated are not co-integrated."

$$
\begin{gathered}
R N G D P_{t}=\alpha_{0}+\sum_{i=1}^{r} \alpha_{x t-i} R N G D P_{t-i}+\sum_{i=1}^{s} \alpha_{y t-i} D E X_{t-i}+\varepsilon_{t} \\
D E X_{t}=\beta_{0}+\sum_{i=1}^{r} \beta_{y t-i} D E X_{t-i}+\sum_{i=1}^{s} \beta_{x t-i} R N G D P_{t-i}+\varepsilon_{t}
\end{gathered}
$$

\subsection{Error Correction Model (ECM)}

When variables are co-integrated, a mechanism is required to correct their state, for which Engle and Granger (1987) provide such a procedure known as the 'Error-Correction Models' (ECM). The aim of ECM is to determine whether co-integration exists between two variables; there must be Granger causality in at least one direction, but the most valuable aspect is that co-integration does not reflect the direction of causality between the variables. The ECM is expressed as in equation (11) and (12):

$$
\begin{aligned}
\Delta Y_{t} & =a_{1}+\beta_{1} E C T_{t-1}+\sum_{i=1}^{n} \delta_{i} \Delta Y_{t-1}+\sum_{i=1}^{n} \Omega_{i} \Delta X_{t-1}+e_{t} \\
\Delta X_{t} & =a_{2}+\beta_{2} E C T_{t-1}+\sum_{i=1}^{n} \mu_{i} \Delta Y_{t-1}+\sum_{i=1}^{n} €_{i} \Delta X_{t-1}+e_{t}
\end{aligned}
$$

where $\left(\mathrm{ECT}_{\mathrm{t}-1}\right)$ is the error correction term lagged one period, is equivalent to $e_{t}=Y_{t}-\alpha-\beta X_{t}$, which represents the disequilibrium residual of a co-integration equation (Fasana and Wang, 2001).

According to Enders (1995: 376), the causality in the ECM is applied in three stages:

(a) Joint Hypothesis:

$\mathrm{H}_{0:} \beta_{1}=0, \mathrm{H}_{0:} \delta_{\mathrm{i}}=0$, for all (i) in equation (11),

or

$\mathrm{H}_{0:} \beta_{2}=0, \mathrm{H}_{0:} \mu_{\mathrm{i}}=0$, for all (i) in equation (12);

(b) Test the significance of $\left(\delta_{\mathrm{i}}\right)$ and $\left(\mu_{\mathrm{i}}\right)$ to check for the possibility of short run causality;

(c) Analysis of the direction of the $\left(\beta^{\prime} s\right)$ to see if they infer a long-run equilibrium relationship.

\section{Empirical Results}

In this paper, the empirical results introduced strong evidence in support of the relationship between defence expenditures and Non Oil economic growth in the case of Saudi Arabia.

\subsection{Stationarity and Unit Root Tests}

Unit-root tested for Augmented Dickey-Fuller test (ADF), as summarised in the table 2. According to the results, each variable for the period 1970-2012 indicates that the series are non-stationary in level but stationary after the first difference.

Table 2. Unit Root Tests for Non Oil GDP

\begin{tabular}{lll}
\hline Variables & ADF $(0)$ & ADF $(1)$ \\
\hline L (RNGDP) & -1.8562 & -5.4882 \\
L (DEX) & -2.5371 & -4.5332 \\
$5 \%$ C-Value & -2.9565 & -3.5953 \\
\hline
\end{tabular}


Table 2, presents the stationary tests results showing that the variables are non-stationary in levels, but become stationary with the first difference; in other words, they are integrated in order one, when their first differences 1(1) are stationary. These results are consistent with the standard theory, which assumes that most macroeconomic variables are not static, but become stationary in the first difference (Enders, 1995).

\subsection{Co-integration Test}

In the next step, the co-integration test is applied to examine a long-run relationship between the variables by using the OLS test, and the results of which are illustrated in Table 3 for Non Oil real GDP.

Table 3. Co-integration Results for Non Oil-Real GDP, 1970-2012

\begin{tabular}{llllll}
\hline Dependent Variables & Coefficient & T-Stat & Probability & $\mathrm{R}^{2}$ & $\mathrm{DW}$ \\
\hline $\mathrm{L}(\mathrm{DEX})$ & 1.451 & 37.12 & 0.005 & 0.903 & 0.890 \\
\hline
\end{tabular}

Table 3 presents the co-integration test results for the time-series data 1970-2012 used in this study. They show that there is a long-run relationship between defence expenditure (DEX) and economic growth (GDP) for Non Oil real GDP in Saudi Arabia. The variable used for the period 1970-2012 indicates that the series are non-stationary in level, but stationary after the first difference, which suggests that they are I (1).

The following section tests and reports the findings after the co-integration test for Non Oil real GDP using the Johansen co-integration test. The existence of a co-integration vector is pointed out by a trace test since the t-test value exceeds the critical value of $5 \%$ level of significance. This means that co-integration tests are statistically significant at $5 \%$ level of significance for determining the long-run relationship between all variables. Otherwise, there is a long-run equilibrium relationship between real Non Oil GDP and DEX.

Table 4 shows that there is a long-run equilibrium relationship between Non Oil real GDP and defence expenditure at $5 \%$ levels. Thus, the null hypothesis of co-integration is rejected with respect to Non Oil real GDP because the trace statistics values are greater than the critical value of 5\%. Co-integrated relationships exist with respect to real Non Oil GDP in the case of Saudi Arabia, an even stronger result indicating that the defence expenditure and real Non Oil GDP are subject to an equilibrium relationship in the long run.

Table 4. Johansen Co-integration Test Results with Non Oil-GDP

\begin{tabular}{lllll}
\hline Hypothesized No. of CE(s) & Eigen value & Trace Statistic & Critical Value 5\% & Prob \\
\hline None & 0.2417 & 21.1923 & 15.41 & 0.0000 \\
At most 1 & 0.1966 & 7.5360 & 3.76 & 0.0000 \\
\hline
\end{tabular}

The Johansen and Juselius (1990) test reveals a co-integration relationship in all versions. Therefore, Granger-Causality in the framework of the Error Correction Model is applied.

\subsection{Granger Causality Test}

For supporting defence expenditure model for Non Oil GDP, causality analysis is considered to apply for testing the directions of the variables. Granger causality tests used to confirm the causality direction between the variables. In the long run, we found statistically significant evidence in favour of GDP Granger-causing the share of defence expenditures in GDP. The result of causality test indicated that the existence of strong feedback causality for all variables of defence expenditure model in the long run.

In relation to the aims of research, the analysis showed clear evidence and consistent results across the model of defence expenditure that there is a significant or causal relationship between, defence expenditure and Non Oil GDP, in the case of Saudi Arabia.

The results established for the causality from defence expenditures (DEX) to economic growth. Therefore, in such cases, bi-directional causality is found. 
Table 5. Standard Granger Causality Test Results

\begin{tabular}{lll}
\hline Null Hypothesis & F-Stat & Prob \\
\hline LRNGDP does not Granger Cause LDEX & 4.2451 & 0.041 \\
LDEX does not Granger Cause LRNGDP & 2.7453 & 0.152 \\
\hline
\end{tabular}

\subsection{Error Correction Model (ECM)}

The next section extends the analysis into Error Correction Mechanism (ECM) in order reveal the short-run adjustment. Thus, the model of defence expenditure has found to hold for Non Oil-GDP in table 6 in the case of Saudi Arabia.

Table 6 shows a bi-directional causality that runs from Non Oil-GDP to DEX this product of empirical analysis indicates that the variables used in each of the models DEX, and Non Oil-GDP is statistically significant at the 5\% level. Thus, in Saudi Arabia, the model of defence expenditure is found to hold for Non Oil-GDP.

Table 6. Causality with ECM Test with Non Oil-GDP

\begin{tabular}{lll}
\hline Variables & $\mathrm{ECT}_{\mathrm{t}-1}$ & $\mathrm{~T}$-stat \\
\hline $\mathrm{L}(\mathrm{DEX})$ & -0.575341 & -3.631 \\
$\mathrm{~L}(\mathrm{RNGDP})$ & -0.186450 & -1.728 \\
\hline
\end{tabular}

\section{Conclusion}

Our major aim in this paper was to investigate the relationship between defence expenditure (DEX) and Non Oil economic growth (RNGDP) using annual data for period 1970 - 2012.

In extending the analysis, the unit root test in the form of Augmented Dickey-Fuller is utilised to examine stationary of the time-series of all the variables. The results indicate that the levels of all series are non-stationary, and hence all the variables are co-integrated at the first order [I(1)].

The results suggest that there is a co-integrating relationship between defence expenditure and Non Oil GDP, and holds in the case of Saudi Arabia through the co-integration analysis. Therefore, the equilibrium relationship indicates that the major determinant of defence expenditure in Saudi Arabia, in the long run, is national income.

The econometric analysis further employs the Granger causality test in order to verify the causality and its direction between the variables. The results demonstrate statistically significant evidence in favour of Non Oil GDP for the long-run relationship. In addition, it is found that Granger-causing the share of defence expenditure in GDP. This finding is consistent with the expectation of the model of defence expenditure. Thus, the result of the causality test indicates the existence of strong feedback (bi-directional) causality for all variables of the model of defence expenditure in the long run.

Lastly, by using the Error Correction Model (ECM), it is established that the variables of the model of defence expenditure are significant for Non Oil-GDP in the case of Saudi Arabia. This suggests a short-run adjustment process towards long-run equilibrium.

In conclusion, the government should focus on the other sectors and activities such as education, health, and other social programmes. The development plan must take into account how the function of each group complements the functions of the others.

\section{References}

Abu-Bader, S., \& Abu- Qarn, A. (2003). Government Expenditures, Military Spending and Economic Growth: Causality Evidence from Egypt, Israel, and Syria. Journal of Policy Modelling, 25, 567-583. http://dx.doi.org/10.1016/S0161-8938(03)00057-7

Aizenman, J., \& Glick, R. (2003). Military Expenditures, Threats, and Growth, NBER Working Paper, No. 9618.

Al-Jarrah, M. (2005). Defense Spending and Economic Growth in an Oil-Rich Country: The Case of Saudi Arabia. Pakistan Economic and Social Review, 3, 151-166.

Atesoglu, H. S. (2002). Defense Spending Promotes Aggregate Output in the United States Evidence from Cointegration Analysis. Defence and Peace Economics, 13(1), 55- 60. 
Benoit, E. (1973). Defense and Economic Growth in Developing Countries. D.C. Health \& Co., Lexington Books, Boston, MA.

Benoit, E. (1978). Growth and Defense Spending in Developing Countries. Economic Development and Cultural Change, 26, 271-80. http://dx.doi.org/10.1086/451015

Brumm, H. (1997). Military Spending, Government Disarray, and Economic Growth: A cross-country Empirical Analysis. Journal of Macroeconomics, 19, 827-38. http://dx.doi.org/10.1016/S0164-0704(97)00044-X

Chowdhury, A. R. (1991). A Causal Analysis of Defence Spending and Economic Growth. Journal of Conflict Resolution, 35, 80-97. http://dx.doi.org/10.1177/0022002791035001005

Deger, S., \& Sen, S. (1983). Military Expenditure, spin-off and Economic Development. Journal Development Economics, 13, 67- 83. http://dx.doi.org/10.1016/0304-3878(83)90050-0

Deger, S. (1986). Military Expenditure in Third World Countries, RKP, London.

Dickey, D. A., \& Fuller, W. A. (1979). Distribution of the Estimators for Autoregressive Time Series with a Unit Root. Journal of the American Statistical Association, 74, 427-431.

Dickey, D. A., \& Fuller, W. A. (1981). Likelihood Ratio Statistics for Autoregressive Time Series with a Unit Root. Econometrica, 49, 1057-1072. http://dx.doi.org/10.2307/1912517

Enders, W. (1995). Applied Econometric Time Series (1st ed.). Wiley, J. and Sons, Inc. New York.

Engle, R. F., \& Granger, C. W. J. (1987). Co-Integration and Error Correction: Representation, Estimation, and Testing. Econometrica, 55, 251-276. http://dx.doi.org/10.2307/1913236

Fiani, R., Annez, P., \& Taylor, L. (1984). Defense Spending, Economic Structure, and Growth: Evidence Among Countries and Over Time. Economic Development and Cultural Change, 32, 487-98. http://dx.doi.org/10.1086/451402

Frederiksen, P. C., \& McNab, R. (2001). The Relationship Between Defense Spending and Economic Growth: A Granger Causality Analysis for Malaysia, 1961-1999. J. Strategic Stud. Int. Relat., 9(1), 63-71.

Granger, C. W. J. (1980). Testing for Causality. Journal of Economic Dynamics and Control, 2, 329-352. http://dx.doi.org/10.1016/0165-1889(80)90069-X

Granger, C. W. J. (1988). Some Recent Developments in a Concept of Causality. Journal of Econometrics, 39, 199-211. http://dx.doi.org/10.1016/0304-4076(88)90045-0

Halicioglu F. (2004). Defense Spending and Economic Growth in Turkey: An Empirical Application of New Macroeconomic Theory, Rev. Middle East Econ. Fin, 2(3), 193-201. http://dx.doi.org/10.2202/1475-3693.1028

Hassan, M. K., Waheed Uzzaman, M., \& Rahman. A. (2003). Defense Expenditure and Economic Growth in the SAARC countries. The Journal of Political, Social and Economic Studies, 28(3), 275-293.

International Monetary Fund. (IMF). Government Financial Statistics Yearbook. Washington: International Monetary Fund, 2001 to 2010.

Kentor, J., \& Kick, E. (2008). Bringing the Military Back in, Journal of World-Systems Research, XIV(2), $142-172$.

Kollias, C., Naxakis, C., \& Zarangas, L. (2004). Defense Spending and Growth in Cyprus: A Causal Analysis. Jouranla. Defence. Peace Econ, 15(3), 299-307. http://dx.doi.org/10.1080/1024269032000166864

Kim,H. (1996).Trade-offs Between Military Spending, Quality of Life and Economic Growth. Comparative Economic Studies, 38, 69-84. http://dx.doi.org/10.1057/ces.1996.40

Klein, T. (2004). Military Expenditure and Economic Growth: Peru1970-1996. Journal of Defense and Peace. Economics, 15, 275-287. http://dx.doi.org/10.1080/102426903200035101

Lim, D. (1983). Another Look at Growth and Defense in less Developed Countries. Economic Development and Cultural Change, 3, 377-84. http://dx.doi.org/10.1086/451326

Lipow, J., \& Antinori, C. M. (1995). External Security Threats, Defence Expenditures, and the Economic Growth of Less Developed Countries. Journal of Policy Modelling, 17, 579-595. http://dx.doi.org/10.1016/0161-8938(95)00021-6

Moon, C. I., \& Hyun, I. T. (1992) Muddling Through Security, Growth and Welfare: The Political Economy of Defense Spending in South Korea, In Steve Chan and Alex Mintz (Eds), Defence, Welfare and Growth. 
New York, Routledge.

Oskooee, B. M., \& Alse, S. (1993). Export Growth and Economic Growth: An Application of Co-integration and Error Correction Modelling. The Journal of Developing Areas, 27, 535-542.

SAMA. Annual Report. (2001 to 2009). The Saudi Arabia Monetary Agency.

Sezgin, Selami, \& Yildirim, Jülide. (2002). The Demand for Turkish Defence Expenditure, Defence and Peace Economics. Special Issue on Military Affairs in Turkey and Greece, 13(2) 121-128.

Sezgin, Selami, \& Yildirim, Jülide. (2005). Democracy and Military Expenditure: A Cross-Country Evidence. Transition Studies Review, 12(1), 93-100. http://dx.doi.org/10.1007/s11300-005-0037-0

SIPRI (Stockholm International Peace Research Institute). World Armaments and Disarmaments. SIPRI yearbook, Oxford University Press, Oxford (various years). http://milexdata.sipri.org 